\title{
New advances in understanding the heterohelicid planktic foraminifer early evolution
}

\author{
Marius D. GEORGESCU* \\ Department of Geosciences, University of Calgary, 2500 University Drive NW, Calgary, Alberta T2N 1N4, Canada
}

Received 20 June 2013; accepted 14 October 2013

Available online 28 October 2013

DOI: http://dx.doi.org/10.5038/1937-8602.58.2.3

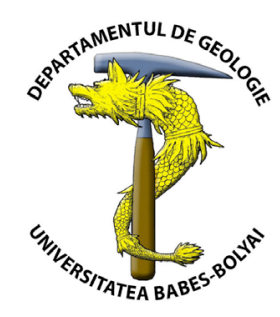

\begin{abstract}
Three Late Cretaceous lineages of heterohelicid planktic foraminifera, which evolved in the proximity of the Cenomanian/Turonian boundary, bring new data in understanding the group evolutionary history. Lunatriella Eicher and Worstell, 1970a is a directional lineage of late Cenomanian-early Turonian age, which gradually develops peripheral backward extensions in the last-formed chambers. Steineckia Georgescu, 2009a of the Turonian is the earliest heterohelicid lineage that evolved ornamentation consisting of pore mounds; a gap spanning the latest Turonian-early Santonian separates it from Laeviheterohelix Nederbragt, 1991 of the late Santonian-Campanian, the second lineage that developed ornamentation consisting of pore mounds. Pseudoplanoglobulina Aliyulla, 1977 evolved in the early Turonian and is the first heterohelicid lineage that developed multichamber growth in the adult stage; it became extinct in the Santonian. The three directional lineages show that the iterative and convergent evolution patterns occur extensively in the early heterohelicid history.
\end{abstract}

Key words: planktic foraminifera, Late Cretaceous, evolutionary classification

\section{INTRODUCTION}

Heterohelicids represent a group of planktic foraminifera in which at least one growth stage consists of chambers alternately added with respect to the test growth axis resulting in biserial chamber arrangement. The earliest representatives of this group were completely biserial and the development of multichamber growth in the adult stage and/or early planispiral coil are later developments in the evolutionary history of the heterohelicids. Representatives of this group of planktic foraminifera are included in the family Heterohelicidae Cushman, 1927.

The earliest heterohelicids were described in the nineteenth century (Ehrenberg, 1839, 1843, 1844, 1854; Reuss, 1861; Rzehak, 1891, 1895) and significant advances in understanding the group taxonomy and stratigraphical distribution were made only in the twentieth century (Cushman, 1926, 1927, 1928, 1938; Loeblich, 1951; Brönnimann and Brown, 1953; Montanaro Gallitelli, 1957; Aliyulla, 1965; Pessagno, 1967; Brown, 1969). The use of the scanning electron microscope (SEM) in the study of Cretaceous planktics, which began in the late 1960s, increased the observation resolution and this has resulted in an increase of the number of species, genera and suprageneric categories (Eicher and Worstell, 1970a, b; Masters, 1976, 1977; Aliyulla, 1977; Nederbragt, 1989a, b, 1991, 1993; Georgescu, 2007a, b, 2009a, 2010). The first attempt to reconstruct the group's evolutionary history was made by Aliyulla (1965), who considered that the heterohelicids first occurred in the stratigraphic record in the late Early Cretaceous and underwent a significant diversification in the Coniacian-Santonian; the group continued its evolution in the Cenozoic despite an abrupt reduction in diversity at the
Cretaceous/Paleogene boundary (Aliyulla, 1965, p. 217-218). Subsequent studies showed relative agreement in regards to the heterohelicid first occurrence: late Albian (Brown, 1969; Masters, 1977; Aliyulla, 1977; Nederbragt, 1991; Georgescu, 2009b); two older first occurrences for the group were given by Fuchs $(1973,1975)$ in the Oxfordian and Pessagno (1967) in the Aptian. However, significant differences exist between various authors in estimating the group diversification: Turonian (Pessagno, 1967; Aliyulla, 1977; Nederbragt, 1991), Coniacian (Aliyulla, 1965; Brown, 1969) and Santonian (Masters, 1977).

New advances in understanding the heterohelicid evolutionary history became possible with the large-scale use of the scanning electron microscope and by considering the taxonomic significance of the test ultrastructure, ornamentation, pore characteristics, and high-detail morphological features (e.g., periapertural structures, position and shape of the backward projections of the last-formed chambers, etc.). Georgescu (2009b) demonstrated the benthic origins of the heterohelicid planktics, thereby showing that the planktic foraminifera represent a polyphyletic group rather than a unitary plexus; this evolutionary process happened in the late Albian (Pseudothalmanninella ticinensis Biozone) and Protoheterohelix Georgescu and Huber, 2009, the oldest heterohelicid genus, which is also the only genus in the late Albian-early Cenomanian, is characterized by asymmetrical tests and periapertural structures. The group gradually evolved in the middle and late Cenomanian and the earliest completely symmetrical test in edge view occurred in the middle Cenomanian: Planoheterohelix Georgescu and Huber, 2009. The oldest heterohelicid ornamented with thin costae 
(leptocostae) evolved in the late Cenomanian: Globoheterohelix Georgescu and Huber, 2009; apparently the ornamented tests evolved independently in the Planoheterohelix lineage, namely in the species P. postmoremani Georgescu and Huber, 2009. Turonian heterohelicid assemblages worldwide show the development of elaborated morphological features, such as backward chamber peripheral extensions (e.g., Lunatriella Eicher and Worstell, 1970a), chamber backward extension (e.g., Huberella Georgescu, 2007a) and ornamentation consisting of pore mounds (e.g., Steineckia Georgescu, 2009a).

High resolution SEM-based studies provide a clearer view on the heterohelicid taxonomy and evolution when compared to those based on the observations made under the optical stereomicroscope. The advantage resides in the fact that observations of the wall ultrastructure, ornamentation features, porosity, as well as discrete morphological features (e.g., periapertural structures symmetry/asymmetry and characteristics, chamber backward extensions, etc) collected on well-preserved specimens and in stratigraphic context can be readily incorporated into a more accurate taxonomic and evolutionary framework. A SEM-based study in the proximity of the Cenomanian/Turonian boundary as part of the ongoing process of development of an evolutionary classification for the Cretaceous heterohelicids provides new insights on the group's early evolution. Three directional lineages are defined in evolutionary classification: Lunatriella, Steineckia and Pseudoplanoglobulina. Understanding the evolutionary developments in these three lineages is of paramount importance in understanding the early heterohelicid evolution and the morphological advances in the group history prior to the major Santonian diversification.

\section{MATERIAL STUDIED AND METHODOLOGY}

Collection specimens and new material collected from Deep Sea Drilling Project (DSDP)/Ocean Drilling Program (ODP) sites were used in this study (Fig. 1). Material provenance, quantity and preservation state are presented in Table 1 . The SEM was extensively used in collecting morphological data; more than 400 micrographs were taken in order to make high resolution observations on the test wall ultrastructure, ornamentation, porosity and discrete test morphological features.

The collection specimens used in this study are deposited in the University of Colorado Museum in Boulder, Colorado (UCM), National Museum of Natural History in Washington, D.C. (USNM) and Naturkundemuseum in Berlin (ECO). Locality and sample labelling for the onshore material (Kansas and South Dakota, USA) is that used in the original articles

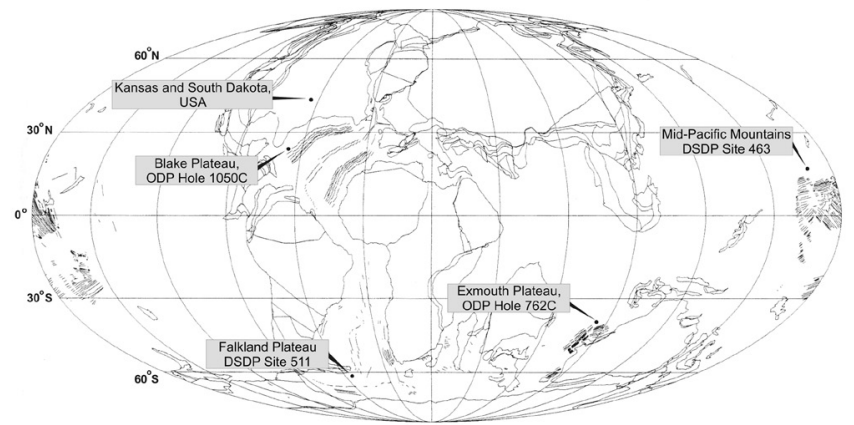

Fig. 1. Geographic locations of the sites that provided the foraminiferal material used in this study. Base map after Hay et al. (1999). by Eicher and Worstell (1970a, b). The standard DSDP sample labelling system is used for the four sections offshore [DSDP Site 463 of the Mid-Pacific Mountains (Central Pacific Ocean), DSDP 511 of the Falkland Plateau (South Atlantic Ocean), ODP Hole $762 \mathrm{C}$ of the Exmouth Plateau (eastern Indian Ocean), and ODP Hole 1050C of the Blake Plateau (North Atlantic Ocean)]: leg number-site number-core number-section number, sample depth in centimetres.

\section{SYSTEMATIC CLASSIFICATION}

Higher categories are after Loeblich and Tappan (1987); evolutionary classification units are after Georgescu (2010, 2012). The concept of composite paleontological species (Georgescu and Huber, 2009) is followed throughout. The terminology for the transition from biserial to uniserial chamber arrangement is from Kaminski et al. (2011).

\section{Directional Lineage Lunatriella Eicher and Worstell, 1970a - emended}

Lunatriella gen. nov. Eicher and Worstell, 1970a, p. 117.

Lunatriella Eicher and Worstell, 1970. Loeblich and Tappan, 1987, p. 454.

Species included. Initiating species (IS): L. fayose (Petters, 1983), first descendant species (FDS): L. digitata (Masella, 1959) and second descendant species (SDS): L. spinifera Eicher and Worstell, 1970a.

Emended diagnosis. Late Cenomanian-early Turonian biserial to lax-uniserial planktics that gradually develop peripheral backward chamber extensions and leptoflanges.

Emended description. Test with chambers added alternating to the test growth axis resulting in a biserial arrangement, which may become loosely biserial and finally lax uniserial in later chambers. Earlier chambers are subglobular, those of the adult stage reniform. One peripheral backward chamber extension occurs in the first descendant and second descendant species, but is absent in the initiating species. Sutures are distinct and depressed, straight to curved and oblique to the test growth axis. Test is compressed and symmetrical in edge view; periphery is rounded and simple, lacking peripheral structures. Aperture is a high arch at the base of the last-formed chamber. Symmetrically developed orthoflanges border it on each side in the initiating and first descendant species; leptoflanges are developed in the second descendant species. Chamber surface is smooth. Test wall is calcitic, hyaline and perforate; pores are simple and circular, with a diameter of $0.4-1.2 \mu \mathrm{m}$.

$\underline{\text { Remarks. }}$ Lunatriella is emended to accommodate a lineage of late Cenomanian-early Turonian age. The evolution in this lineage led to the development of chambers with peripheral backward extensions, which is in the incipient stage in the first descendant species and well developed in the second descendant species, and terminally lax-uniserial chamber arrangement and aperture bordered by leptoflanges in the second descendant species. The species included in Lunatriella have a smooth chamber surface and simple and circular pores $(0.4-1.0 \mu \mathrm{m})$; additional well-preserved specimens are necessary to study the pore size evolution along the lineage. Lunatriella evolved from the smooth species of Planoheterohelix in the late Cenomanian; the lineage initiation happened with the development of reniform chambers in the adult stage in L. fayose.

Age. Late Cenomanian-Early Turonian. 
Table 1. Foraminiferal material used in this study: provenance, quantity and preservation state.

\begin{tabular}{|c|c|c|c|c|}
\hline & Site/age & Species & Specimen number & Preservation \\
\hline \multirow{9}{*}{ 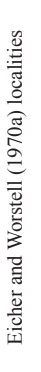 } & \multirow{3}{*}{$\begin{array}{l}\text { Locality } 2 \text { - Fall River County, South Dakota - early } \\
\text { Turonian }\end{array}$} & Lunatriella fayose & 2 & excellent \\
\hline & & L. digitata & 1 & excellent \\
\hline & & L. spinifera & 3 & excellent \\
\hline & \multirow[t]{4}{*}{ Locality 5 - Hamilton County, Kansas - early Turonian } & Lunatriella fayose & 23 & excellent \\
\hline & & L. digitata & 6 & excellent \\
\hline & & L. spinifera & 12 & excellent \\
\hline & & Steineckia sp. & 4 & excellent \\
\hline & \multirow[t]{2}{*}{ Locality 6 - Hamilton County, Kansas - early Turonian } & Lunatriella fayose & 9 & excellent \\
\hline & & Steineckia sp. & 3 & excellent \\
\hline \multirow{4}{*}{ 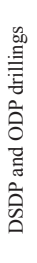 } & $\begin{array}{l}\text { DSDP Site } 463 \text { - Mid-Pacific Mountains, Central Pacific } \\
\text { Ocean - Turonian to early Santonian }\end{array}$ & Pseudoplanoglobulina directa & circa 100 & very good \\
\hline & $\begin{array}{l}\text { DSDP Site } 511 \text { - Falkland Plateau, South Atlantic Ocean } \\
\text { - late Turonian }\end{array}$ & Pseudoplanoglobulina directa & 14 & excellent \\
\hline & $\begin{array}{l}\text { ODP Hole } 762 \mathrm{C} \text { - Exmouth Plateau, eastern Indian Ocean } \\
\text { - Turonian-Santonian }\end{array}$ & Pseudoplanoglobulina directa & circa 60 & very good \\
\hline & $\begin{array}{l}\text { ODP Hole } 1050 \mathrm{C} \text { - Blake Plateau, North Atlantic Ocean - } \\
\text { early Turonian }\end{array}$ & Pseudoplanoglobulina directa & 18 & very good \\
\hline$\stackrel{\Xi}{0}$ & $\begin{array}{l}\text { Upper Missouri, Ehrenberg Collection, samples } 1595 \mathrm{~b} \text { and } \\
1595 \mathrm{f} \text { - late Santonian }\end{array}$ & Pseudoplanoglobulina directa & 11 & excellent \\
\hline \multicolumn{3}{|c|}{ Legend - Preservation } & & \\
\hline & excellent & pristine tests; original calcite is often preserved & & \\
\hline & very good & $\begin{array}{l}\text { test recrystallized but detail morphological features } \\
\text { (including ultrastructure) can be adequately observed }\end{array}$ & & \\
\hline
\end{tabular}

Geographic distribution. Europe (Italy), USA (Colorado, Kansas, South Dakota, Utah, Wyoming), western Africa (Senegal) and western Central Atlantic Ocean (Demerara Rise).

\section{Lunatriella fayose (Petters, 1983) - emended Fig. 2: 1-16}

Heterohelix pulchra (Brotzen 1936). Eicher and Worstell, 1970a, pl. 1, figs 1-2.

Heterohelix pulchra (Brotzen 1936). Eicher and Worstell, 1970b: 296, pl. 8, fig. 9.

Heterohelix fayose sp. nov. Petters, 1983, p. 43, pl. 1, figs 8-10.

Heterohelix pulchra (Brotzen 1936). Friedrich et al., 2008, pl. 1, fig. 17.

Emended diagnosis. Lunatriella with globular or reniform chambers in the adult stage.

Emended description. Test consists of 8-11 chambers. Proloculus is followed by chambers that are alternately added with respect to the test growth axis resulting in a biserial arrangement; earlier chambers are subglobular, those in the adult stage reniform. Sutures are distinct and depressed, straight to curved, and oblique to the test growth axis; subtriangular depressed areas occasionally occur along the central zigzag suture due to the chamber reniform shape. Test compressed and symmetrical in edge view, with rounded and simple periphery. Aperture is a high arch at the base of the last-formed chamber; symmetrically developed orthoflanges border the aperture on each side. Chamber surface is smooth. Test is calcitic, hyaline and perforate; pores are simple, circular in shape, and have a diameter of 0.9-1.0 $\mu \mathrm{m}$.

Remarks. Lunatriella fayose differs from Planoheterohelix moremani (Cushman, 1938) by (i) reniform chambers in the adult stage, (ii) less evident chamber overlapping, and (iii) larger pores $(0.9-1.0 \mu \mathrm{m}$ rather than $0.5-0.7 \mu \mathrm{m})$.

Age. Late Cenomanian-Early Turonian.

Geographic distribution. USA (Colorado, South Dakota) and western Africa (Nigeria).

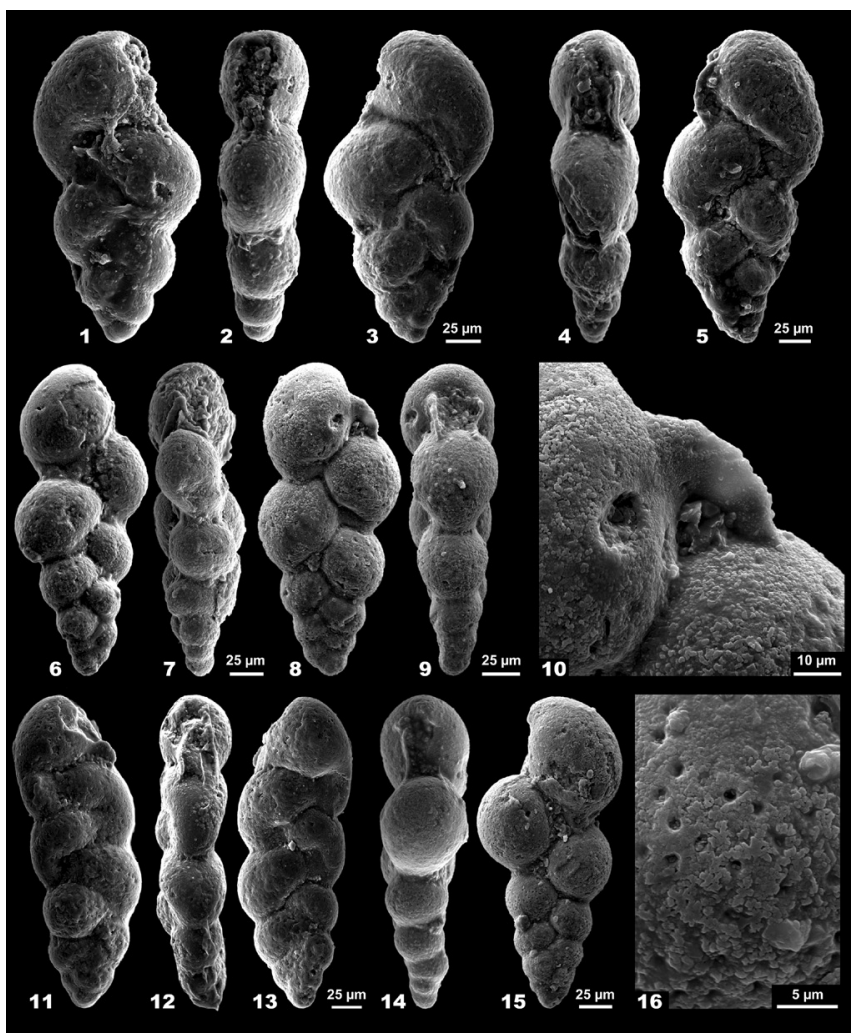

Fig. 2. Hypotypes of Lunatriella fayose (Petters, 1983) from the Fairport Shale Member (early Turonian) of Kansas and South Dakota, USA. 1-3) Specimen from Locality 5 of Eicher and Worstell, 1970a, Sample 62 (UCM 27866), previously figured by Eicher and Worstell (1970a, pl. 1, fig. 1 and 1970b, pl. 8, fig. 9); Hamilton County, Kansas; 4-5) Specimen from Locality 2 of Eicher and Worstell, 1970a, Sample 46; Fall River County, South Dakota; 6-7) Specimen from Locality 5 of Eicher and Worstell, 1970a, Sample 62; Hamilton County, Kansas; 8-10) Specimen from Locality 5 of Eicher and Worstell, 1970a, Sample 62; Hamilton County, Kansas; 11-13) Specimen from Locality 5 of Eicher and Worstell, 1970a, Sample 62; Hamilton County, Kansas; 14-16) Specimen from Locality 5 of Eicher and Worstell, 1970a, Sample 62; Hamilton County, Kansas. 


\section{Lunatriella digitata (Masella, 1959)}

Fig. 3: 1-13

Heterohelix digitata sp. nov. Masella, 1959, p. 15, pl. 1, figs 1-10. Heterohelix pulchra (Brotzen, 1936). Eicher and Worstell, 1970a, pl. 1, fig. 4.

Lunatriella spinifera Eicher and Worstell 1970a. Eicher and Worstell, 1970a, pl. 1, fig. 5.

Heterohelix digitata Masella, 1959. Masters, 1977, p. 341

Heterohelix americana (Ehrenberg, 1843). De Klasz et al., 1995, p. 361, pl. 5, figs 5-7, pl. 2, figs 1-2.

Lunatriella spinifera (Eicher and Worstell, 1970a). Friedrich et al., 2008, pl. 1, figs 18-19.

Heterohelix americana (Ehrenberg, 1843). Georgescu and Huber, 2009, p. 348, pl. 6, figs 1-6.

Diagnosis. Lunatriella with the last-formed chambers with an incipient peripheral backward extension.

Description. Test consists of 8-11 chambers. Proloculus is followed by chambers that are alternately added with respect to the test growth axis resulting in biserial chamber arrangement. Earlier chambers are subglobular then reniform; last-formed one or two chambers with one more or less developed peripheral backward extension. Test is compressed and asymmetrical in

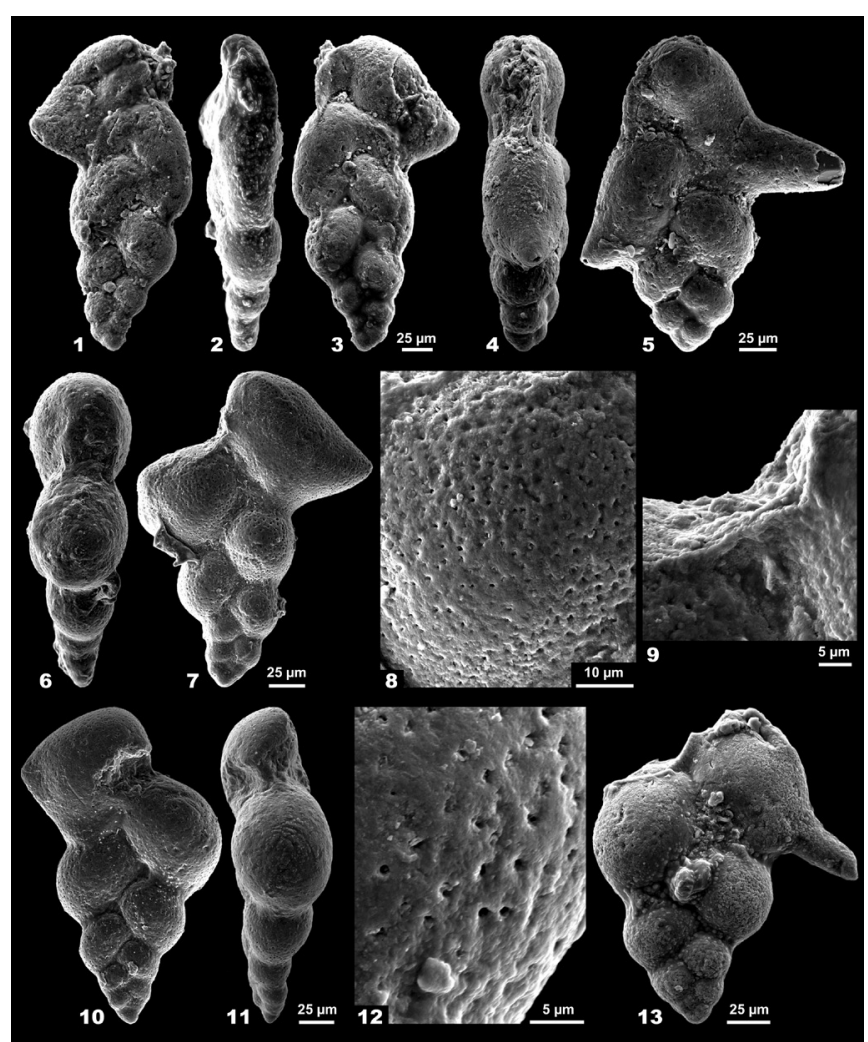

Fig. 3. Hypotypes of Lunatriella digitata (Masella, 1959) from the Fairport Shale Member (early Turonian) of Kansas, USA (1-5, 13) and uppermost Cenomanian-lowermost Turonian sediments of Senegal, well Rd2. 1-3) Specimen from Locality 5 of Eicher and Worstell, 1970a, Sample 62 (UCM 27869), previously figured by Eicher and Worstell (1970a, pl. 1, fig. 4); Hamilton County, Kansas; 4-5) Specimen from Locality 5 of Eicher and Worstell, 1970a, Sample 62; Hamilton County, Kansas; 6-9) Specimen from well R2d of Senegal, Sample 1651-1660 m (USNM 473378), previously figured by Georgescu and Huber (2009, pl. 6, figs 1-3); 10-12) Specimen from well R2d of Senegal, Sample 1651-1660 m (USNM 473378), previously figured by Georgescu and Huber (2009, pl. 6, figs 4-6); 13) Specimen from Locality 2 of Eicher and Worstell, 1970a, Sample 46; Fall River County, South Dakota. edge view, and with rounded and simple periphery. Aperture is a high arch at the base of the last-formed chamber, and is bordered by orthoflanges symmetrically developed on each side. Chamber surface is smooth. Test calcitic, hyaline and perforate; pores are simple, circular and with a diameter of 0.4-0.9 $\mu \mathrm{m}$.

Remarks. The emendation is made to include the test ultrastructure features and periapertural structure redescription. Lunatriella digitata differs from $L$. fayose by having the lastformed one or two chambers with one peripheral backward extension and a tendency to become loosely biserial (sensu Kaminski et al., 2011).

Age. Latest Cenomanian-Early Turonian.

Geographic distribution. Europe (Italy), USA (Colorado, South Dakota), western Africa (Senegal) and western Central Atlantic Ocean (Demerara Rise).

\section{Lunatriella spinifera Eicher and Worstell, 1970a} Fig. 4: 1-12

Lunatriella spinifera sp. nov. Eicher and Worstell, 1970a, p. 118, pl. 1, figs 6-17.

Lunatriella spinifera Eicher and Worstell, 1970a. Eicher and Worstell, 1970b, p. 296, pl. 8, figs 7-8, 12.

Lunatriella spinifera Eicher and Worstell, 1970a. Masters, 1977, p. 358, pl. 3, figs 5-6.

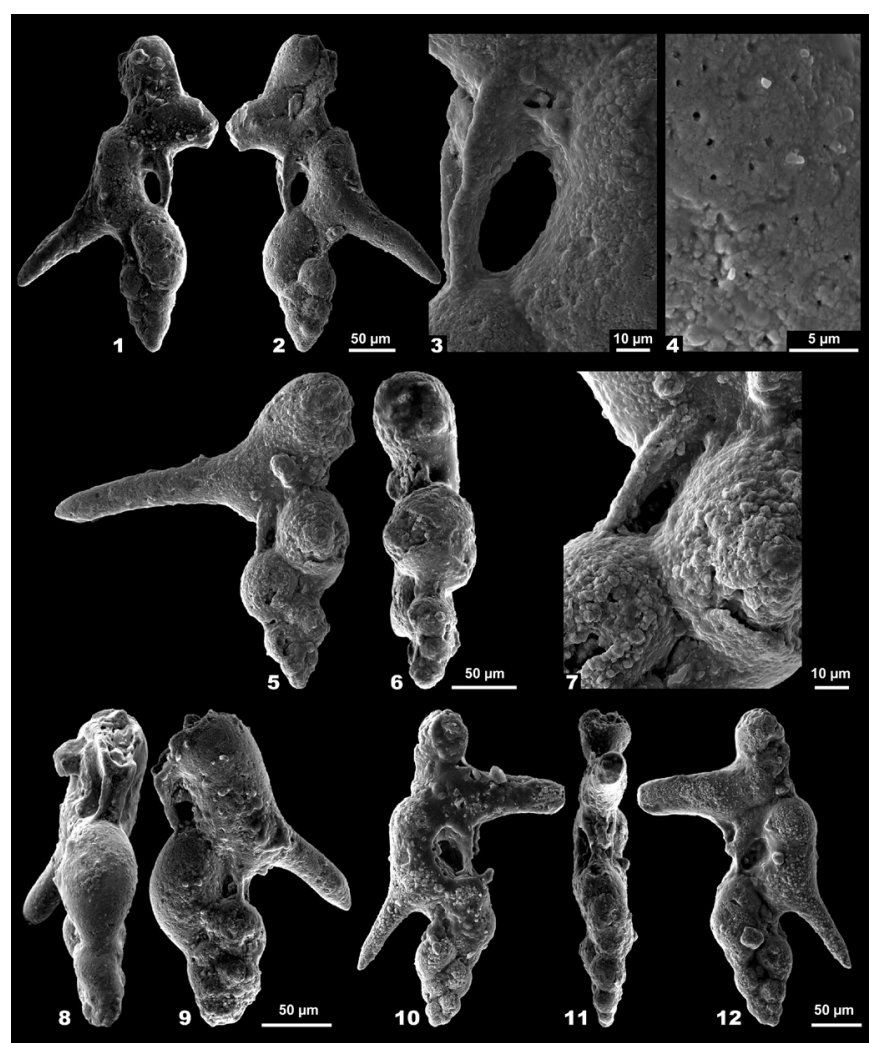

Fig. 4. Holotype and paratypes of Lunatriella spinifera Eicher and Worstell, 1970 a from the Fairport Shale Member (early Turonian) of Kansas, USA. 1-4) Holotype from Locality 5 of Eicher and Worstell, 1970a, Sample 62 (UCM 27375), previously figured by Eicher and Worstell (1970a, pl. 1, fig. 6); 5-7) Paratype from Locality 5 of Eicher and Worstell, 1970a, Sample 62 (UCM 27879), previously figured by Eicher and Worstell (1970a, pl. 1, fig. 12); 8-9) Paratype from Locality 5 of Eicher and Worstell, 1970a, Sample 62 (UCM 27878); 10-12) Paratype from Locality 5 of Eicher and Worstell, 1970a, Sample 62 (UCM 27871), previously figured by Eicher and Worstell (1970a, pl. 1, fig. 7 and 1970b, pl. 6, fig. 12). 
Lunatriella spinifera Eicher and Worstell, 1970a. Petters, 1983, p. 45, pl. 1, figs 6-7.

Diagnosis. Lunatriella with the last-formed one or two chambers with well-developed peripheral backward extension.

Description. Test consists of 8-10 chambers. Proloculus is followed by chambers that are alternately added with respect to the test growth axis resulting in biserial arrangement; later chambers become loosely biserial and finally lax-uniserial. Earlier chambers are subglobular, then elongate, with the elongation axis almost parallel to the test growth axis; the last-formed one or two chambers with one well-developed peripheral backward extension, which is oblique to perpendicular to the test growth axis. Sutures are distinct and depressed, straight to curved and oblique to the test growth axis. Test is compressed and symmetrical in edge view; periphery rounded in the test early portion and pinched in the chambers with backward extension. Aperture is a high arch at the base of the lastformed chamber; symmetrically developed leptoflanges, which in the adult stage are attached to the anterior portion of the previous chamber, border the aperture on each side. Chamber surface is smooth. Test wall is calcitic, hyaline and perorate; pores are circular, simple and with diameter of $0.5-1.2 \mu \mathrm{m}$.

Remarks. Lunatriella spinifera is the end member of the Lunatriella directional lineage. It differs from L. fayose and L. digitata mainly by (i) its tendency for chambers to become loosely biserial and finally lax-uniserial in later chambers, (ii) the well-developed peripheral backward extensions of the lastformed one or two chambers, and (iii) aperture bordered by leptoflanges. It is the first species to develop leptoflanges in the heterohelicid group; similar structures occur through iterative evolution in a species of the late Campanian-Maastrichtian, namely Braunella brauni Georgescu, 2007b.

\section{Age. Early Turonian.}

Geographic distribution. USA (Colorado, Kansas, South Dakota, Utah, Wyoming), western Africa (Nigeria) and western Central Atlantic Ocean (Demerara Rise).

\section{Directional Lineage Steineckia, Georgescu 2009a}

Steineckia gen. nov. Georgescu, 2009a, p. 325.

Species included. IS: Steineckia sp. and FDS: S. steinecki Georgescu, 2009a.

Diagnosis. Late Cenomanian-Turonian lineage of planktic foraminifera with chambers alternately added with respect to the test growth axis resulting in a biserial arrangement and ornamentation consisting of large pore mounds (3.1-6.4 $\mu \mathrm{m})$.

Description. The test consists of chambers alternately added with respect the test growth axis resulting in biserial arrangement. Earlier chambers are subglobular, those in the adult stage reniform, and with a subtriangular-rounded depression in the posterior part in the initiating species. Sutures are distinct and depressed, straight to curved and oblique to the test growth axis. Test compressed and symmetrical in edge view; periphery is rounded, simple. Aperture a medium high arch at the base of the last formed chamber; symmetrically developed orthoflanges border the aperture on each side. Chamber surface is ornamented with pore mounds that increase in size from 3.1-5.0 $\mu \mathrm{m}$ in the initiating species to $4.0-6.4 \mu \mathrm{m}$ in the first descendant species. Test wall is calcitic, hyaline and perforate; pore mounds are simple, circular, and with a diameter of $0.4-0.8 \mu \mathrm{m}$.

Remarks. Steineckia is the earliest lineage of Cretaceous planktic foraminifera that developed ornamentation consisting of pore mounds; it became extinct near the Turonian/Coniacian boundary. The second and last known lineage of serial planktics that developed ornamentation consisting of pore mounds is Laeviheterohelix Nederbragt, 1991, which was emended and redefined as a directional lineage in the evolutionary classification by Georgescu (2009a). Its reviewed stratigraphic range is upper Santonian-Campanian. No tests with pore mounds are known from the Coniacian-lower Santonian stratigraphic interval. Steineckia differs from the Laeviheterohelix lineage by lacking the pustulose periapertural area and having the chamber surface ornamented with larger pore mounds (3.1-6.4 $\mu \mathrm{m}$ rather than 1.7-2.8 $\mu \mathrm{m}$ ) (Georgescu, 2009a).

Age. Turonian.

Geographic distribution. Falkland Plateau (South Atlantic Ocean) and USA (Colorado, South Dakota, Wyoming).

\section{Steineckia sp.}

\section{Fig. 5: 1-12}

Heterohelix pulchra (Brotzen, 1936). Eicher and Worstell, 1970a, pl. 1, fig. 3.

Heterohelix pulchra (Brotzen, 1936). Friedrich et al., 2008, pl. 1, fig. 17.

Diagnosis. Steineckia with elongate test.

Description. Test consists of 11-13 chambers. Proloculus is small, and followed by chambers that are added alternately with respect to the test growth axis; early chambers subglobular, those in the adult stage reniform, with a subtriangular-rounded depression in the posterior part. Sutures are distinct and depressed, straight to curved function of the development of reniform chambers, and oblique to the test growth axis. Test is compressed and symmetrical in edge view; periphery rounded and simple. Aperture is a medium high at the base of the last-formed chamber; symmetrically developed orthoflanges border the aperture on each side. Chamber surface is ornamented with circular pore mounds, with a diameter of 3.1-5.0 $\mu \mathrm{m}$. Test wall is calcitic, hyaline and perforate; pores simple and circular (0.5-0.8 $\mu \mathrm{m}$ in diameter), and are situated at the center of or, more rarely between the pore mounds.

Remarks. Steineckia sp. differs from $S$. steinecki by (i) the test consisting of more chambers (11-13 rather than 10-11), (ii) smaller $\mathrm{W} / \mathrm{L}$ ratio that results in a narrower test and with elongate aspect, and (iii) smaller pore mounds (3.1-5.0 $\mu \mathrm{m}$ rather than 4.0-6.4 $\mu \mathrm{m}$ ). It differs from $L$. fayose by (i) the test consisting of more chambers (11-13 rather that 8-11), and (ii) chamber surface ornamented with pore mounds rather than smooth. It differs from Laeviheterohelix pulchra (Brotzen, 1936) by (i) the test with fewer chambers (11-13 rather than 15-18), (ii) ornamentation consisting of larger pore mounds (3.1-5.0 $\mu \mathrm{m}$ rather than 1.7-2.8 $\mu \mathrm{m}$ ) and (iii) by lacking the pustulose periapertural area.

Age. Early Turonian.

Geographic distribution. USA (Colorado, South Dakota, Wyoming).

\section{Directional lineage Pseudoplanoglobulina Aliyulla, 1977 - emended}

Tesserella gen. nov. Aliyulla, 1977, p. 204.

Pseudoplanoglobulina gen. nov. Aliyulla, 1977, p. 204.

Pseudoplanoglobulina Aliyulla, 1977. Loeblich and Tappan, 1987, p. 455.

Species included. IS: $P$. directa (Aliyulla, 1965) and FDS: $P$. nakhitschevanica Aliyulla, 1977. 


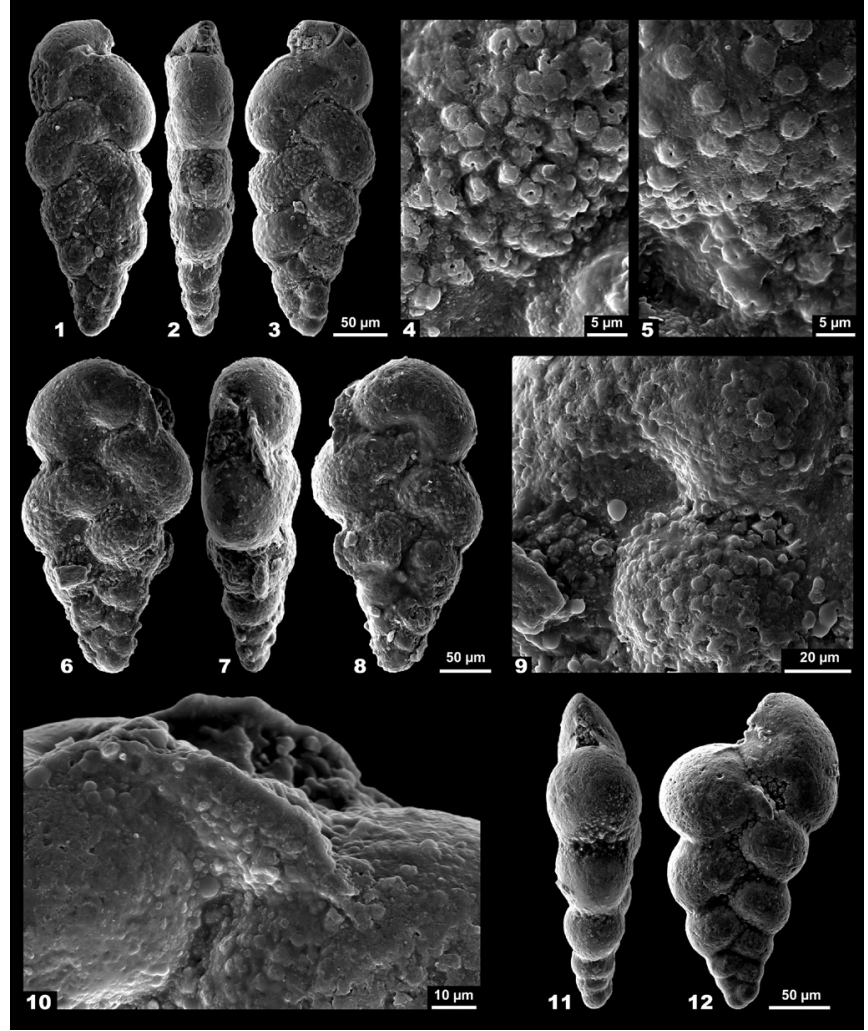

Fig. 5. Hypotypes of Steineckia sp. from the Fairport Shale Member (early Turonian) of Kansas, USA. 1-5) Specimen from Locality 5 of Eicher and Worstell, 1970a, Sample 62; Hamilton County, Kansas; 6-10) Specimen from Locality 5 of Eicher and Worstell, 1970a, Sample 62 (UCM 27868), previously figured by Eicher and Worstell (1970a, pl. 1, fig. 3 and 1970b, pl. 8, fig. 10), Hamilton County, Kansas; 11-12) Specimen from Locality 5 of Eicher and Worstell, 1970a, Sample 62; Hamilton County, Kansas.

Emended diagnosis. Turonian-Santonian lineage of serial planktics with smooth chamber surface and orthoflanges bordering the aperture, which develop multichamber growth in the adult stage.

Emended description. Test in the initiating species consists of chambers alternately added with respect to the test growth axis resulting in a biserial arrangement; first descendant species is characterized by multichamber growth in the adult stage. Early chambers are subglobular, and subrectangular or reniform in the last growth stage. Sutures are distinct and depressed, straight and oblique to the test growth axis. Test compressed and symmetrical in edge view, with rounded and simple periphery. Aperture is a low to medium high arch at the base of the last-formed chamber; aperture singular in the biserial tests and multiple in those with multichamber growth in the adult stage. Symmetrical orthoflanges border the aperture on each side. Chamber surface is smooth, excepting for the periapertural pustulose area. Test wall is calcitic, hyaline and perforate. Pores are simple and circular, with a diameter of 0.4-1.0 $\mu \mathrm{m}$.

Remarks. Pseudoplanoglobulina is reviewed in evolutionary classification to accommodate a lineage of heterohelicids with periapertural structures consisting of orthoflanges, smooth chamber surface, and simple and small pores $(0.4-1.0 \mu \mathrm{m}$ in diameter). Multichamber growth occurs in the first descendant species ( $P$. nakhitschevanica) of the early Turonian, which evolved from the initiating species $(P$. directa), a completely biserial species of the Turonian-Santonian. Aliyulla (1977) described two genera based on the two species: Tesserella and Pseudoplanoglobulina respectively. Tesserella was described as having smooth or pustulose ornamentation; Aliyulla (1977) made this genus unusable by choosing the costate $T$. pseudotessera (Cushman 1938) of the Campanian-Maastrichtian its type species. Pseudoplanoglobulina is thereby preferred, although its description follows that of Tesserella in the original work (Aliyulla 1977).

Age. Turonian-Santonian.

Geographic distribution. Cosmopolitan.

\section{Pseudoplanoglobulina directa (Aliyulla, 1965) - emended} Fig. 6: 1-16

Gümbelina tessera (Ehrenberg, 1854). Cushman, 1932, p. 338, pl. 51, figs 4-5.

Gümbelina tessera (Ehrenberg, 1854). Loetterle, 1937, p. 34, pl. 5 , fig. 4 .

Heterohelix (Chiloguembelina) pseudotessera Cushman subsp. directa ssp. nov. Aliyulla, 1965, p. 224, pl. 1, fig. 1.

Tesserella pseudotessera (Cushman, 1938). Aliyulla, 1977, pl. 3, figs 1-3.

Heterohelix pulchra (Brotzen, 1936). Frerichs et al., 1975, p. 301, pl. 1, figs 7-8.

Heterohelix pulchra (Brotzen, 1936). Petters, 1980, pl. 1, fig. 17.

Heterohelix pulchra (Brotzen, 1936). Petters, 1983, p. 43, pl. 1 , figs $18,20$.

Diagnosis. Pseudoplanoglobulina with chambers alternately added with respect to the test growth axis resulting in biserial chamber arrangement.

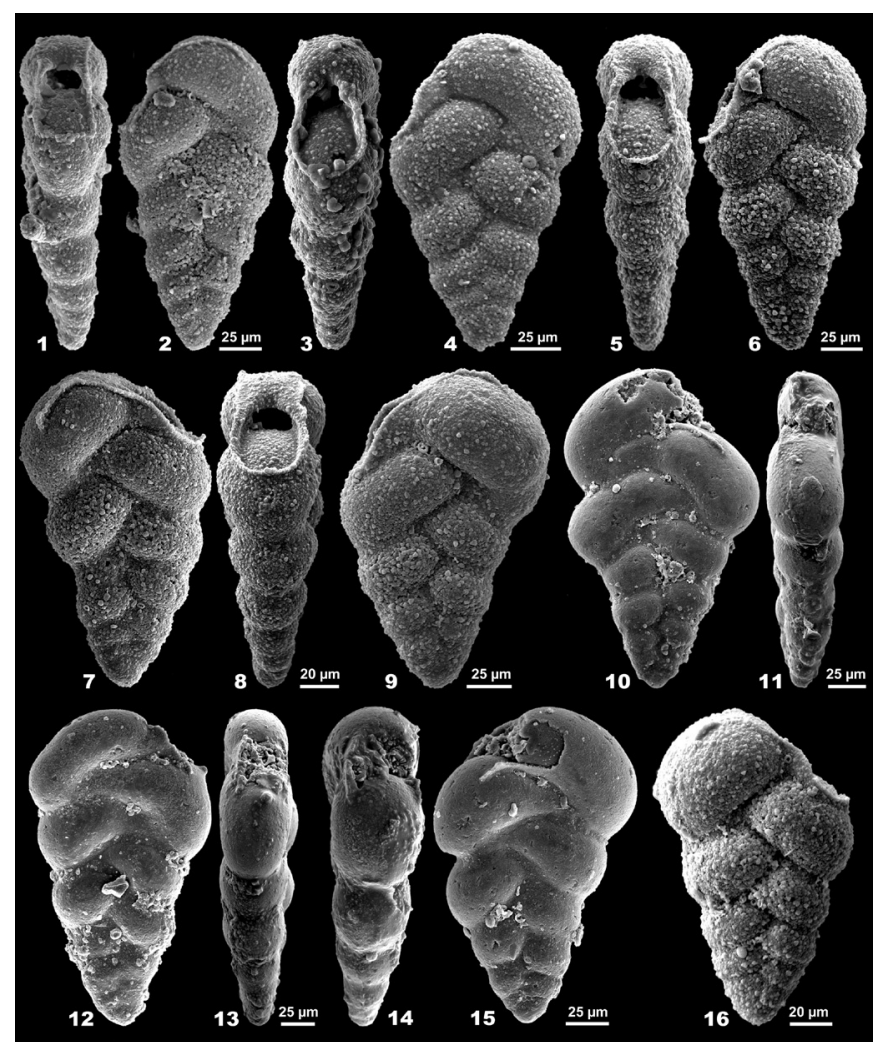

Fig. 6. Hypotypes of Pseudoplanoglobulina directa (Aliyulla, 1965) from the Coniacian-lower Santonian sediments of the DSDP Site 463 (MidPacific Mountains, Central Pacific Ocean) (1-9, 16) and upper Santonian Niobrara Formation, Smoky Hill Shale Member of Upper Missouri from the Ehrenberg Collection (10-15). 1-9, 16) Sample 62-463-26-5, 53-58 cm (Coniacian-lower Santonian); 10-11) Specimen ECO 053-05; 12-13) Specimen ECO 053-10; 14-15) Specimen ECO 053-07. 
Description. Test consists of 12-15 chambers. Proloculus is small, followed by alternating chambers with respect to the test growth axis resulting in a biserial arrangement. Early chambers are subglobular, those of the adult stage subrectangular, then reniform. Sutures are distinct, depressed, straight and oblique to the test growth axis. Test is compressed and symmetrical in edge view; periphery is rounded and lacks peripheral structures. Aperture is a low to medium high arch at the base of the lastformed chamber; symmetrical orthoflanges border the aperture on each side. Chamber surface is smooth; periapertural pustulose area occurs in the chamber anterior portion. Test wall is calcitic, hyaline and perforate; pores are simple, circular, and with a diameter of $0.4-1.0 \mu \mathrm{m}$.

Remarks. Pseudoplanoglobulina directa differs from $P$. nakhitschevanica by lacking the multichamber growth in the adult stage. It differs from L. fayose by (i) the less developed chamber overlapping and (ii) straight and simple sutures between the lastformed chambers rather than with subtriangular depressed areas. It differs from Protoheterohelix obscura Georgescu and Huber, 2009 of the Late Albian-Early Turonian by having (i) symmetrical tests in edge view and (ii) symmetrically developed periapertural structures. It differs from L. pulchra by (i) the test consisting of fewer chambers (12-15 rather than 15-18) and (ii) chamber surface smooth rather than ornamented with pore mounds. The taxonomical revision of $P$. directa was in parallel with that of L. pulchra because they can be easily confused for each other in the optical microscope-based studies; the similarities in the test architecture and the fact that the smooth species $(P$. directa) precedes the ornamented one (L. pulchra) in the stratigraphic record may indicate a possible phylogenetic relationship between them. Georgescu (2009a, fig. 8: 3a-c) illustrated longitudinal ornamentation structures coexisting with the pore mounds in $L$. pulchra; such structures were interpreted as vestigial costae and were considered an argument demonstrating that L. pulchra evolved from the costate species P. planata (Cushman, 1938). With the taxonomic revision of $P$. directa it appears more plausible to consider the origins of L. pulchra among this smooth species; in this new interpretation, the short longitudinal structures with the same ultrastructure as the test wall, can only represent temporary structures generated during pore mound development.

Age. Turonian-Santonian.

Geographic distribution. Cosmopolitan.

\section{DISCUSSION AND CONCLUSIONS}

New data on three heterohelicid lineages that evolved near the Cenomanian/Turonian boundary provide interesting insights on the early evolution of the group. For the first time it can be demonstrated the extensive branching generated by the convergent and iterative evolution patterns in the early evolution of this planktic foraminiferal group (Fig. 7), a perspective that contrasts to those elaborated by Masters (1977) and Nederbragt (1991), in which fewer than five species of late Albian-Turonian age were recognized.

Lunatriella is redefined as a directional lineage in the evolutionary classification; it evolved from $P$. moremani in the latest Cenomanian (Petters, 1983), and continued its evolution in the early Turonian. Lunatriella fayose of the late

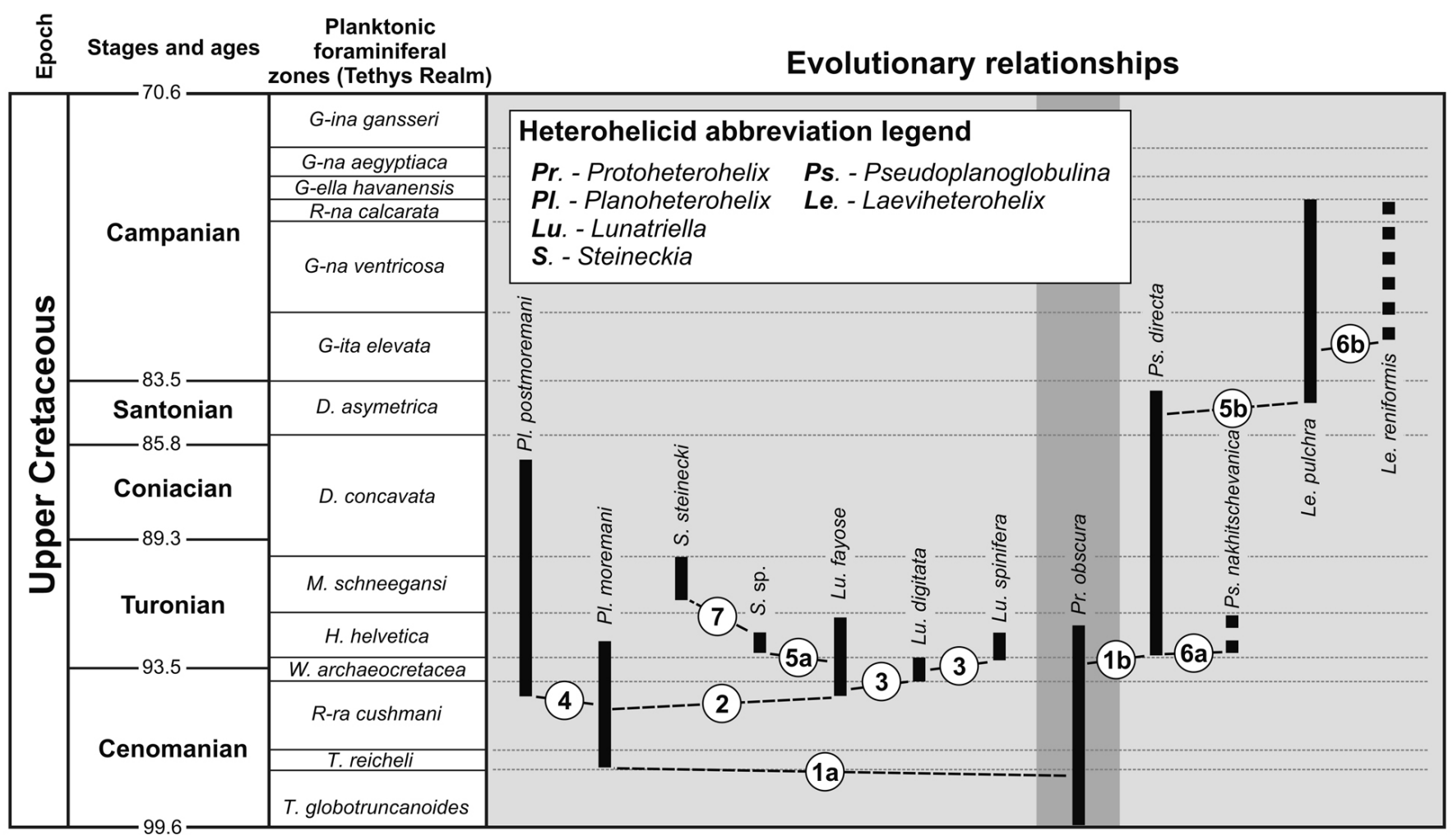

Fig, 7. Evolutionary relationships and major trends among some Cenomanian-Campanian heterohelicids, showing the lineage Lunatriella, Steineckia and Pseudoplanoglobulina origins. Background legend: dark grey-tests with asymmetrical periapertural structures; light greycompletely symmetrical tests. Trend legend: $\mathbf{1} \boldsymbol{a}-\boldsymbol{b})$ development of symmetrical tests; 2) development of reniform chambers in the adult stage with a subtriangular depression towards the posterior part; 3) development of peripheral chamber backward extensions; 4) development of costate ornamentation; $\mathbf{5 a}$-b) development of ornamentation consisting of pore mounds; $\mathbf{6} \boldsymbol{a}-\boldsymbol{b})$ development of multichamber growth in the adult stage; 7-loss of elongate test aspect through the reduction of chamber number. Ages are after Gradstein et al. (2004). Planktic foraminiferal zonation is after Robaszynski and Caron (1995); abbreviated genera in the biozonation framework: D=Dicarinella, G-ella=Globotruncanella, G-ina=Gansserina, G-ita=Globotruncanita, G-na=Globotruncana, H=Helvetoglobotruncana, M=Marginotruncana, R-na=Radotruncana, R-ra=Rotalipora and $\mathrm{T}=$ Thalmanninella. 
Cenomanian-early Turonian is the initiating species, and it evolved through the development of reniform chambers in the adult stage. The first and second descendant species, $L$. digitata and L. spinifera gradually develop peripheral chamber backward extension and a tendency to become lax-uniserial, which is in an incipient stage in the former and well-developed in the latter. Periapertural structures consist of orthoflanges in the initiating and first descendant species and leptoflanges in the second descendant. Tests included in the Lunatriella lineage have smooth tests, simple test wall, and simple and circular pores, with a diameter of 0.4-1.0 $\mu \mathrm{m}$.

Steineckia is emended and redefined as a directional lineage in the evolutionary classification. Specimens of the early Turonian herein assigned to Steineckia sp. have ornamentation consisting of pore mounds (3.1-5.0 $\mu \mathrm{m}$ in diameter), demonstrating that the lineage evolved earlier than late Turonian as previously considered by Georgescu (2009a); additional material is necessary to clarify the taxonomic status of Steineckia sp. The first descendant species is $S$. steinecki of the upper Turonian sediments of the Falkland Plateau (South Atlantic Ocean). The Steineckia directional lineage evolved from $L$. fayose as indicated by the similarities in the test architecture and occurrences in sediments at the same stratigraphical level.

Pseudoplanoglobulina is emended to accommodate a lineage consisting of unornamented heterohelicids. The initiating species is $P$. directa of the Turonian-Santonian, which has a biserial chamber arrangement; the first descendant species, $P$. nakhitschevanica, of early Turonian age developed a multichamber growth in the adult stage. Pseudoplanoglobulina is the earliest known lineage in the heterohelicid evolutionary history that led to the development of multichamber growth in the adult stage.

The taxonomic re-evaluation of the three lineages, as part of the ongoing process of developing an evolutionary classification framework for the Cretaceous planktic foraminifera casts a new perspective on the heterohelicid early evolution, and helps in assessing the effects of convergent and iterative patterns in the group evolutionary history. The heterohelicid group evolved in the late Albian from the small calcareous benthic foraminifers of the genus Praeplanctonia Georgescu 2009b (Georgescu, 2009b). The earliest heterohelicids are included in the genus Protoheterohelix Georgescu and Huber, 2009, and they form a lineage in which the major evolutionary trend is the gradual achievement of symmetrical tests in edge view; P. obscura, which is the latest evolved species of Protoheterohelix, has the test asymmetry reduced to that of the periapertural structures (archaeoflanges) (Georgescu, 2010).

The evolution of completely symmetrical tests in edge view was achieved in the middle Cenomanian as demonstrated by the P. obscura-P. moremani lineage (Georgescu, 2009b; Georgescu and Huber, 2009). It is shown in this study that completely symmetrical tests iteratively evolved in the early Turonian, in the $P$. obscura- $P$. directa lineage (Fig. 7). In addition, the evolutionary relationships inferred between the species of the Cenomanian-Campanian lineages considered in this study show that all the features in the heterohelicid test morphology occurred iteratively in different lineages, and each lineage has its own evolutionary trends.

Acknowledgements. Dr. D. L. Eicher (University of Colorado) is thanked for allowing the restudy of the USA Western Interior heterohelicids and presubmittal review of the manuscript, which could not have been written without his help. The DSDP/ODP headquarters are thanked for allowing re-sampling of four the wells drilled under the program auspices. Dr L. V. Hills (University of Calgary) is thanked for the manuscript presubmittal review. The help of Dr M. Schoel (Microscopy and Imaging Facility, University of Calgary) during the SEM operations is gratefully acknowledged.

\section{REFERENCES}

Aliyulla, K. 1965, The state of the knowledge of the Family Heterohelicidae and the way of its subsequent study. Voprosii Mikropaleontologii, 9: 215-228. [in Russian]

Aliyulla, K. 1977, Upper Cretaceous and foraminiferal development in the Lesser Caucasus (Azerbaydzhan). Akademia Nauk Azerbaydzhanskoy SSR, Institut Geologia im. Akad. I. M. Gubkina. Izdatelstvo "Elm”, Baku [in Russian]

Brown, N.K. Jr. 1969, Heterohelicidae Cushman, 1927, amended, a Cretaceous planktonic foraminiferal family. In: P. Brönnimann, P. \& H.H. Renz (eds.), Proceedings of the First International Conference on Planktic Microfossils, Geneva 1967, E.J. Brill, Leiden, 2: 21-67.

Brönnimann, P. \& Brown, N.K. Jr. 1953, Observations on some planktonic Heterohelicidae from the Upper Cretaceous of Cuba. Contributions from the Cushman Foundation for Foraminiferal Research, 4: 150-156.

Brotzen, F. 1936, Foraminiferen aus dem schwedischen unterer Senon von Eriksdal in Schonen. Sveriges Geologiska Untersökning Arsbok, 30: 1-206.

Cushman, J.A. 1926, Some foraminifera from the Mendez Shale of eastern Mexico. Contributions from the Cushman Laboratory for Foraminiferal Research, 2: 16-28.

Cushman, J.A. 1927, An outline of a re-classification of the foraminifera. Contributions from the Cushman Laboratory for Foraminiferal Research, 3: 1-105.

Cushman, J.A. 1928, Additional genera of foraminifera. Contributions from the Cushman Laboratory for Foraminiferal Research, 4: 1-8.

Cushman, J.A. 1932, The foraminifera of the Annona Chalk. Journal of Paleontology, 6: 330-345.

Ehrenberg, C.G. 1839, Über die Bildung der Kreidefelsen und des Kreidemergels durch unsichtbare Organismen. Abhandlungen der Königlichen Akademie der Wissenschaften zu Berlin, 1838: 59-147.

Ehrenberg, C.G. 1843, Verbreitung und Einflufs der mikroscopischen Lebens in Süd- und Nord-Amerika. Abhandlungen der Königlichen Akademie der Wissenschaften zu Berlin, 1841(1): 291-445.

Ehrenberg, C.G. 1844, Eine Mittbeilung über 2 neue Lager von Gebirgsmassen aus Infusorien als Meeres-Absatz in Nord-Amerika und eine Vergleichung derselben mit den organischen Kreide-Gebilden in Europa und Afrika. Bericht über die zur Bekanntmachung geeigneten Verhandlungen der Königlich Preußischen Akademie der Wissenschaften zu Berlin, 1844: 57-98.

Ehrenberg, C.G. 1854, Mikrogeologie. L. Voss, Leipzig, 374 p.

Eicher, D.L. \& Worstell, P. 1970a, Lunatriella, a Cretaceous heterohelicid foraminifer from the western interior of the United States. Micropaleontology, 16: 117-121. http://dx.doi.org/10.2307/1484852 
Eicher, D.L. \& Worstell, P. 1970b, Cenomanian and Turonian foraminifera from the Great Plains, United States. Micropaleontology, 16: 269-324.

http://dx.doi.org/10.2307/1485079

Frerichs, W.E., Atherton, C.C. \& Shive, P.N. 1975. Planktonic foraminifera from the chalky members of the Niobrara formation, Centennial Valley, Wyoming. Journal of Foraminiferal Research, 5: 294-312. http://dx.doi.org/10.2113/gsjfr.5.4.294

Friedrich, O., Norris, R.D., Bornemann, A., Beckmann, B., Pälike, H., Worstell, P., Hofmann, P. \& Wagner, T. 2008, Cyclic changes in Turonian to Coniacian planktic foraminiferal assemblages from the tropical Atlantic Ocean. Marine Micropaleontology, 68: 299-313. http://dx.doi.org/10.1016/j.marmicro.2008.06.003

Fuchs, W. 1973, Ein beitrag zur Kenntnis der Jura"Globigerinen" und verwandter Formen an hand polnischen Materials des Callovien und Oxfordien. Verhandlungen der Geologischen Bundesanstaldt, 3: 445-487.

Fuchs,W.1975,ZurStammesgeschichtederPlanktonforaminiferen und verwandter Formen im Mesozoicum. Jahrbuch der Geologischen Bundesanstaldt 118: 193-246.

Georgescu, M.D. 2007a, A new planktonic heterohelicid foraminiferal genus from the Upper Cretaceous (Turonian). Micropaleontology, 53: 212-220.

http://dx.doi.org/10.2113/gsmicropal.53.3.212

Georgescu, M.D. 2007b, Taxonomic re-evaluation of the Late Cretaceous serial planktic foraminifer Gümbelina punctulata Cushman, 1938 and related species. Revista Española de Micropaleontologia, 39: 155-167.

Georgescu, M.D. 2009a, Taxonomic revision and evolutionary classification of the biserial Cretaceous planktic foraminiferal genus Laeviheterohelix Nederbragt, 1991. Revista Mexicana de Ciencias Geológicas, 26: 315-334.

Georgescu, M.D. 2009b, On the origins of Superfamily Heterohelicacea Cushman, 1927 and polyphyletic nature of planktonic foraminifera. Revista Española de Micropaleontología, 41: 107-144.

Georgescu, M.D. 2010, Origin, taxonomic revision and evolutionary classification of the late Coniacian-early Campanian planktic foraminifera with multichamber growth in the adult stage. Revista Española de Micropaleontología, 42: 59-118.

Georgescu, M.D. 2011. Iterative evolution, taxonomic revision and evolutionary classification of the praeglobotruncanid planktic foraminifera, Cretaceous (late Albian-Santonian). Revista Española de Micropaleontología, 43: 173-207.

Georgescu, M.D. \& Huber, B.T. 2009, Early evolution of the Cretaceous serial planktic foraminifera (late AlbianCenomanian). Journal of Foraminiferal Research, 39: 335-360. http://dx.doi.org/10.2113/gsifr.39.4.335

Gradstein, F.M., Ogg, J. G., \& Smith, A.G. 2004, A Geologic Time Scale 2004. Cambridge University Press, Cambridge. http://dx.doi.org/10.4095/215638

Hay, W.H., DeConto, R.M., Wold, C.N., Wilson, K.M., Voigt, S., Schulz, M., Wold, A.R., Dullo, W.C., Ronov, A.B., Balukhovsky, A.N. \& Söding, E. 1999, Alternative global Cretaceous paleogeography. In: E. Barrera \& C.C. Johnson (eds.), Evolution of the Cretaceous Ocean-Climate System. Geological Society of America, Special Publication, 332: 1-47.
Kaminski, M.A., Cetean, C.G. \& Tyszka, J. 2011, Nomenclature to describe the transition from biserial to uniserial chamber arrangement in benthic foraminifera. Journal of Micropaleontology, 30: 7-10.

http://dx.doi.org/10.1144/0262-821X10-016

Klasz, I. de, Klasz, S. \& Saint-Marc., P. 1995, Heterohelicids from the Turonian of Senegal (West Africa) with particular emphasis on Heterohelix americana (Ehrenberg). Micropaleontology, 41: 359-368.

http://dx.doi.org/10.2307/1485809

Loeblich, A.R. Jr. 1951, Coiling in the Heterohelicidae. Contributions from the Cushman Foundation for Foraminiferal Research, 2: 106-110.

Loeblich, A.R. Jr. \& Tappan, H. 1987, Foraminiferal genera and their classification. Van Nostrand Reinhold Company, New York, 970 p.

Loetterle, G.J. 1937, The Micropaleontology of the Niobrara Formation in Kansas, Nebraska, and South Dakota. Nebraska Geological Survey Bulletin, 12: 1-73.

Masella, L. 1959, Una nueva specie di Heterohelix del Cretaceo della Sicilia. Rivista Mineraria Siciliana, 55: $15-17$.

Masters, B.A. 1976, Planktonic Foraminifera from the Upper Cretaceous Selma Group, Alabama. Journal of Paleontology, 50: 318-330.

Masters, B.A. 1977, Mesozoic Planktic Foraminifera: a world-wide review and analysis. In: A.T.S. Ramsay (ed.), Oceanic Micropaleontology, Academic Press, LondonNew York-San Francisco, 2: 301-733.

Montanaro Gallitelli, E. 1957, A revision of the foraminiferal family Heterohelicidae. In: A.R.Jr. Loeblich (ed.), Studies in Foraminifera. United States National Museum Bulletin, 215: $133-154$.

Nederbragt, A.J. 1989a, Maastrichtian Heterohelicidae (planktonic foraminifera) from the North West Atlantic. Journal of Micropaleontology, 8: 183-206. http://dx.doi.org/10.1144/jm.8.2.183

Nederbragt, A.J. 1989b, Chamber proliferation in the Cretaceous planktonic foraminifera Heterohelicidae. Journal of Foraminiferal Research, 19: 105-114.

http://dx.doi.org/10.2113/gsjfr.19.2.105

Nederbragt, A.J. 1991, Late Cretaceous biostratigraphy and development of Heterohelicidae (planktic foraminifera). Micropaleontology, 37: 329-372.

http://dx.doi.org/10.2307/1485910

Nederbragt, A.J. 1993, Biometrical analysis of multiserial chamber proliferation in Santonian Heterohelicidae (planktic foraminifera). Journal of Foraminiferal Research, 23: 192-200. http://dx.doi.org/10.2113/gsjfr.23.3.192

Pessagno, E.A. Jr. 1967, Upper Cretaceous planktonic foraminifera from the Western Gulf coastal plain. Palaeontographica Americana, 5: 245-445.

Petters, S.W. 1980, Biostratigraphy of Upper Cretaceous of the Benue Trough, Nigeria. Journal of Foraminiferal Research, 10: 191-204.

http://dx.doi.org/10.2113/gsjfr.10.3.191

Petters, S.W. 1983, Gulf of Guinea planktonic foraminiferal biochronology and geological history of the South Atlantic. Journal of Foraminiferal Research, 13: 32-59. http://dx.doi.org/10.2113/gsjfr.13.1.32 
Reuss, A.E. 1861, Die Foraminiferen der Westphälischen Kreideformation. Sitzungsberichte der K. Akademie der Wissenschaften in Wien, Mathematisch-Naturwissenschaftliche Classe, 40: 147-238.

Robaszynski, F. \& Caron, M. 1995, Foraminifères planctoniques du Crétacé: commentaire de la zonation Europe-Méditerranée. Bulletin de la Société Géologique de France, 6: 681-692.
Rzehak, A. 1891, Die Foraminiferenfauna der alttertiären Ablagerungen von Bruderndorf in Niederosterreich, mit Berüchsichtigung der angeblichen Kreidevorkommens von Leitzersdorf. Annalen des K. K. Naturhistorischen Hofmuseums, 6: 1-12.

Rzehak, A. 1895, Ueber einige merkwürdige Foraminiferen aus dem österreichischen Tertiär. Annalen des K. K. Naturhistorischen Hofmuseums, 10: 216-230. 